\section{Histochemistry in biology and medicine: a message from the citing journals}

\author{
C. Pellicciari \\ Department of Biology and \\ Biotechnology "Lazzaro Spallanzani”, \\ University of Pavia, Italy
}

\section{Abstract}

Especially in recent years, biomedical research has taken advantage of the progress in several disciplines, among which microscopy and histochemistry. To assess the influence of histochemistry in the biomedical field, the articles published during the period 2011-2015 have been selected from different databases and grouped by subject categories. As expected, biological and biomedical studies where histochemistry has been used as a major experimental approach include a wide range of basic and applied researches on both humans and other animal or plant organisms. To better understand the impact of histochemical publications onto the different biological and medical disciplines, it was useful to look at the journals where the articles published in a multidisciplinary journal of histochemistry have been cited: it was observed that, in the five-years period considered, $20 \%$ only of the citations were in histochemical periodicals, the remaining ones being in journals of Cell \& Tissue biology, general and experimental Medicine, Oncology, Biochemistry \& Molecular biology, Neurobiology, Anatomy \& Morphology, Pharmacology \& Toxicology, Reproductive biology, Veterinary sciences, Physiology, Endocrinology, Tissue engineering \& Biomaterials, as well as in multidisciplinary journals. It is easy to foresee that also in the future the histochemical journals will be an attended forum for basic and applied scientists in the biomedical field. It will be crucial that these journals be open to an audience as varied as possible, publishing articles on the application of refined techniques to very different experimental models: this will stimulate non-histochemist scientists to approach histochemistry whose application horizon could expand to novel and possibly exclusive subjects.

\section{Introduction}

The wideness of interest of a scientific discipline, and its impact on knowledge and the research progress may be estimated through the number of journals issued in its field, the quantity of articles published in a given timespan, and the number of citations these articles obtained. No doubt, this is a rough estimate but it may allow to quantitate and compare the data taken from qualified databases, and to foresee future developments.

During the last fifteen years, the number of journals published in the biomedical field has significantly increased: for instance, based on the Thomson Reuters' Journal Citation Report (https://jcr.incites.thomsonreuters.com) the journals in the subject categories of Biology increased from 51 to 85, those in Cell Biology from 147 to 184, in Medicine (Experimental \& Research) from 74 to 123 , and in 0ncology from 103 to 211, with an impressive (though hardly computable) surge of published articles.

Research in biomedicine has taken advantage of the progress in several disciplines, first of all in molecular biology and related omics. Microscopy and histochemistry also played a major role, especially in recent years, by providing new instrumentations and refined techniques. ${ }^{1-4}$ In the attempt to assess the impact of histochemistry in the biomedical field, it may be interesting to look at the articles recently published in qualified journals, reporting the results of investigations performed by histochemical methods.

\section{Main subjects of the histo- chemical articles published from 2011 to 2015}

Browsing the records of PubMed (http://www.ncbi.nlm.nih.gov/pubmed/), Web of Science (http://thomsonreuters.com/en/ products-services/scholarly-scientific research/scholarly-search-and-discovery/webof-science.html) and Scopus (http:/www.scopus.com/), the articles published in qualified journals where histochemistry or immunohistochemistry are present in the title/abstract or as key-words were about $87,000,130,000$ and 132,000 respectively, in the last five years (the numerical differences are essentially due to the different journals which are indexed: more medicine-oriented in PubMed, and more widely biology \& medicine-oriented in Web of Science and Scopus).

By grouping these publications in subject categories, according to their contents (Figure 1 ), it is apparent that more than $40 \%$ deal with medical subjects (Pathology \& Experimental Medicine); articles on Differentiation \& Stem cells or Neurons \& Muscle (more than $15 \%$ and $10 \%$, respectively), as well as those on Methods (about 10\%) are also present at high
Correspondence: Prof. Carlo Pellicciari, Dipartimento di Biologia e Biotecnologie "Lazzaro Spallanzani", Università degli Studi di Pavia, Via A. Ferrata 9, 27100 Pavia, Italy.

E-mail: pelli@unipv.it

Key words: Basic and applied histochemistry; biomedical research.

Received for publication: 18 December 2015. Accepted for publication: 21 December 2015.

This work is licensed under a Creative Commons Attribution NonCommercial 3.0 License (CC BYNC 3.0).

(C) Copyright C. Pellicciari, 2015

Licensee PAGEPress, Italy

European Journal of Histochemistry 2015; 59:2610 doi:10.4081/ejh.2015.2610

percentages. About $5 \%$ are those on Animal tissue biology and Hard tissue \& Matrix, and only few on Tissue engineering or on Plant tissue biology.

Thus, in these five recent years, biomedical studies where histochemistry has been used as a major experimental approach included a wide variety of subjects, from basic to applied research on both humans and other animal or plant organisms.

\section{The last five-years record of a multidisciplinary journal of his- tochemistry}

Among the purely histochemical journals, the European Journal of Histochemistry - EJH has traditionally been devoted to publish papers on functional cell and tissue biology in animals and plants, cell differentiation and development, cell-to-cell interaction and molecular trafficking, nerve and muscle cell biology, with special attention to the cellular basis of diseases.

It is worth observing (Figure 1) that some differences exist in the distribution of subjects of the papers published in the European Journal of Histochemistry during the same five-years period, compared to the overall histochemical articles in the literature. Consistent with the latter ones, the majority (about 35\%) of the published articles were on Pathology \& Experimental Medicine, and the percentages found for Hard tissues \& Matrix, Neurons \& Muscle and Plant tissue biology were also similar as those for the whole histochemical production. On the contrary, the percentage of papers published on Animal tissue biology, on Methods and on Tissue engineer- 
ing was higher in the European Journal of Histochemistry, whereas the one on Differentiation \& Stem cells was lower.

Looking at the distribution of articles on these subjects during the last five years (Figure 2) may help to understand how the interests of this journal's authors changed over time, particularly in the most recent time. The articles in Pathology \& Experimental Medicine ranged from more than $40 \%$ to about $20 \%$, having been very numerous in $2013,3^{5-15}$ while progressively decreasing in $2014^{16-29}$ and $20153^{30-40}$; most of these papers were focused on the detection of tumor markers, ${ }_{11,12,14,16,18,1,21,23,28,34}$ but several were aimed at elucidating the mechanisms of carcinogenesis and tumor progression. ${ }^{7,10,13,26,29,33}$ There was steady interest for developmental investigations and stem cell biology with about $15 \%$ of the published articles in the last couple of years: molecular markers of cell differentiation were used to describe the process of placenta formation ${ }^{41,42}$ and organogenesis, ${ }^{43-46}$ and to phenotype stem cells. ${ }^{47,48}$

Extracellular matrix and hard tissues have become increasingly important topics, demonstrating that histochemistry may be suitably applied in particular to investigate cartilage or dentin during the histogenetic process ${ }^{49-51}$ and in pathological conditions; ${ }^{52,56}$ some papers were devoted to the temporomandibular joint in healthy and diseased subjects, ${ }^{50,57-59}$ while other proposed in vitro models for chondrogenesis ${ }^{60-62}$ or dentinogenesis. ${ }^{63}$ Techniques for culture in vitro were also used for tissue engineering, using different supports for growing and differentiating various cell types: ${ }^{64-67}$ Histochemistry thus proved to be an effective mean to characterize the structural and functional features of cells to be used for reconstructive medicine.

The incidence of articles on Neurons \& Muscle has progressively decreased from 2013 to present, although a series of interesting article was published especially for muscle cells. ${ }^{68-81}$ In particular, it was observed that both the ultrastructural organization and the nuclear function of myonuclei and satellite cells' nuclei in the skeletal muscle from patients with myotonic dystrophy were similar to those in the muscles from sarcopenic individuals, suggesting that similar nuclear mechanisms may lead to skeletal muscle wasting. 78,79

There was a steady and progressive rise in the percentage of papers presenting new methods or improved techniques: they were about $12 \%$ of the published articles in $2013^{82-86}$ growing to more than $20 \%$ in 2014 and 2015. .7- $^{87}$ ${ }^{102}$ Actually, this is consistent with the scope of the European Journal of Histochemistry, which has always been an open forum for scientists to present new methods and techniques, and

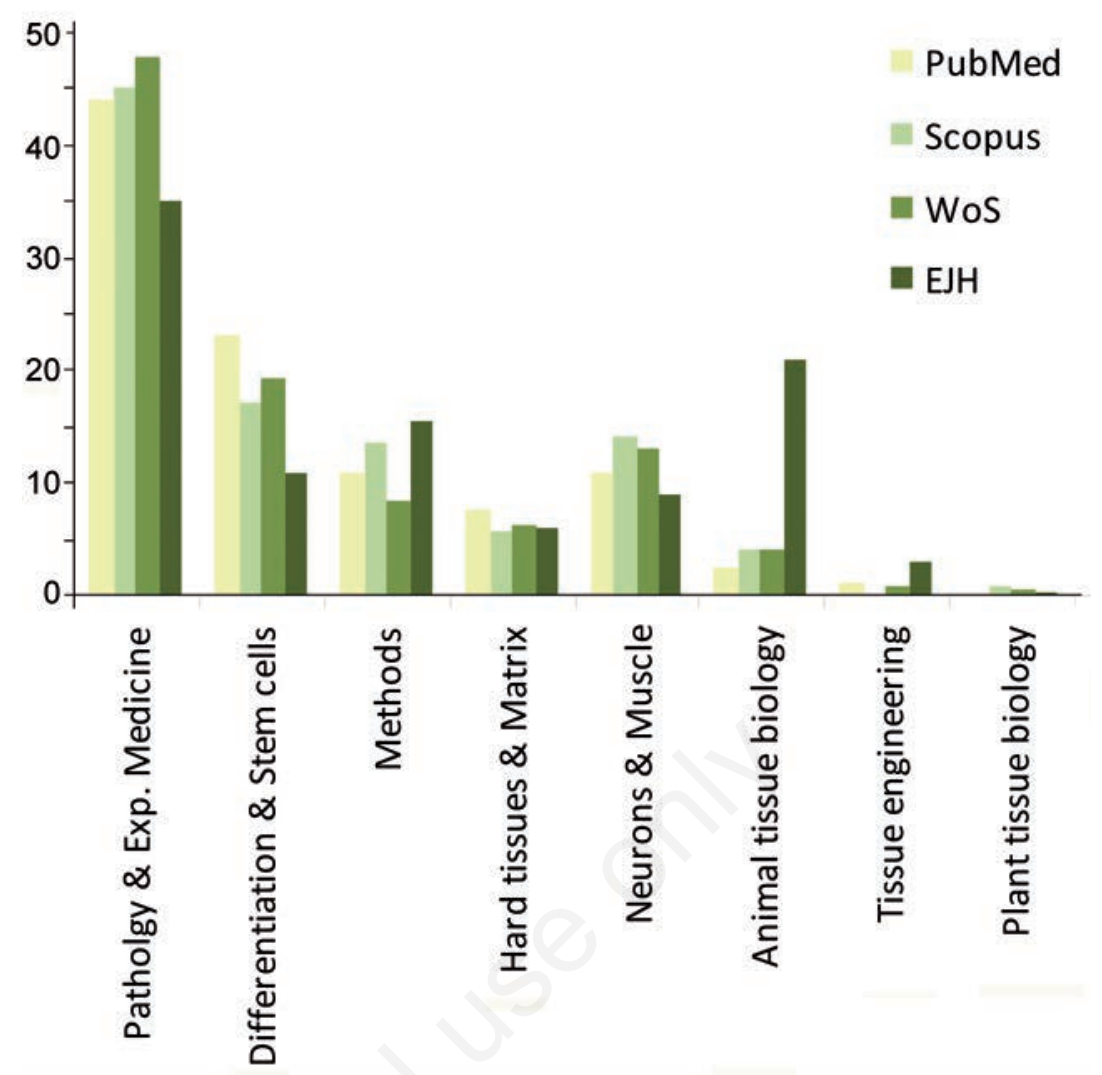

Figure 1. Percentage of histochemical articles published in qualified journals during the period 2011-2015, as from the databases of PubMed, Scopus or Web of Science (WoS). The articles have been divided by subject categories, and their percentages compared to those of the articles published in the European Journal of Histochemistry (EJH), in the same timespan.

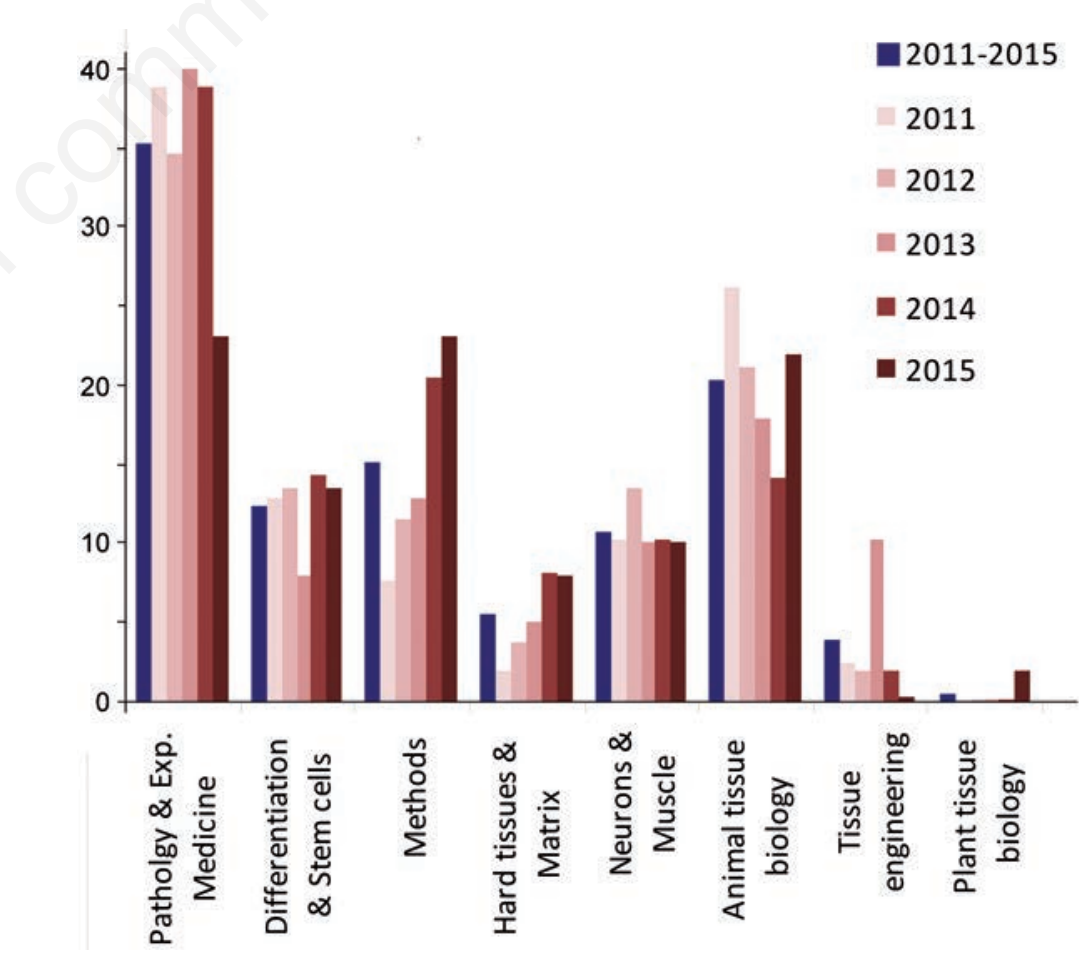

Figure 2. Percentage of articles published yearly in the European Journal of Histochemistry, in the period 2011-2015. The articles have been divided according to their main subjects, as in Figure 1. 
to discuss their experimental results, as it recently occurred for the molecules responsible for some characteristics of cell autofluorescence. ${ }^{89,100-102}$ In the attempt to localize specific molecules at high resolution, ultrastructural cytochemistry proved to be especially suitable, and demonstrated by the several papers published: ${ }^{83,90,93,96}$ In particular, diaminobenzidine photo-oxidation was effectively used to visualize the endocytotic pathways after staining the plasma membrane with a fluorescent dye, ${ }^{93}$ and to simultaneously detect immunogoldlabeled antigens at the high resolution of transmission electron microscopy. ${ }^{83}$

As a journal of functional cytology, the European Journal of Histochemistry has traditionally published many papers on cell and tissue biology in a variety of Vertebrate and Invertebrate species. After a relative decrease in 2013 and $2014,{ }^{103-115}$ in the present year more than $20 \%$ of the published papers were on these subjects, ${ }^{116-126}$ thus demonstrating that histochemical techniques are powerful tools for properly describing cell and tissue organization as well as functional microanatomy in different taxa of still poorly described organisms. In a comparative perspective, the histochemical evidence, in parallel with molecular data on protein and DNA, may help to elucidate the origin and evolution of cell and tissue physiology.

\section{Estimating the impact of the published articles through a survey of the citing journals}

The overall influence of an academic journal on the scientific community is usually estimated by the impact factor, which is a measure reflecting the mean number of citations obtained by recent articles published in a given journal. This index does not take into account the subject category of the journals where the citing articles were published; but especially for journals devoted to a variety of subjects and techniques, as the European Journal of Histochemistry is, it should be interesting to consider this aspect, too.

The more than 200 articles published in the
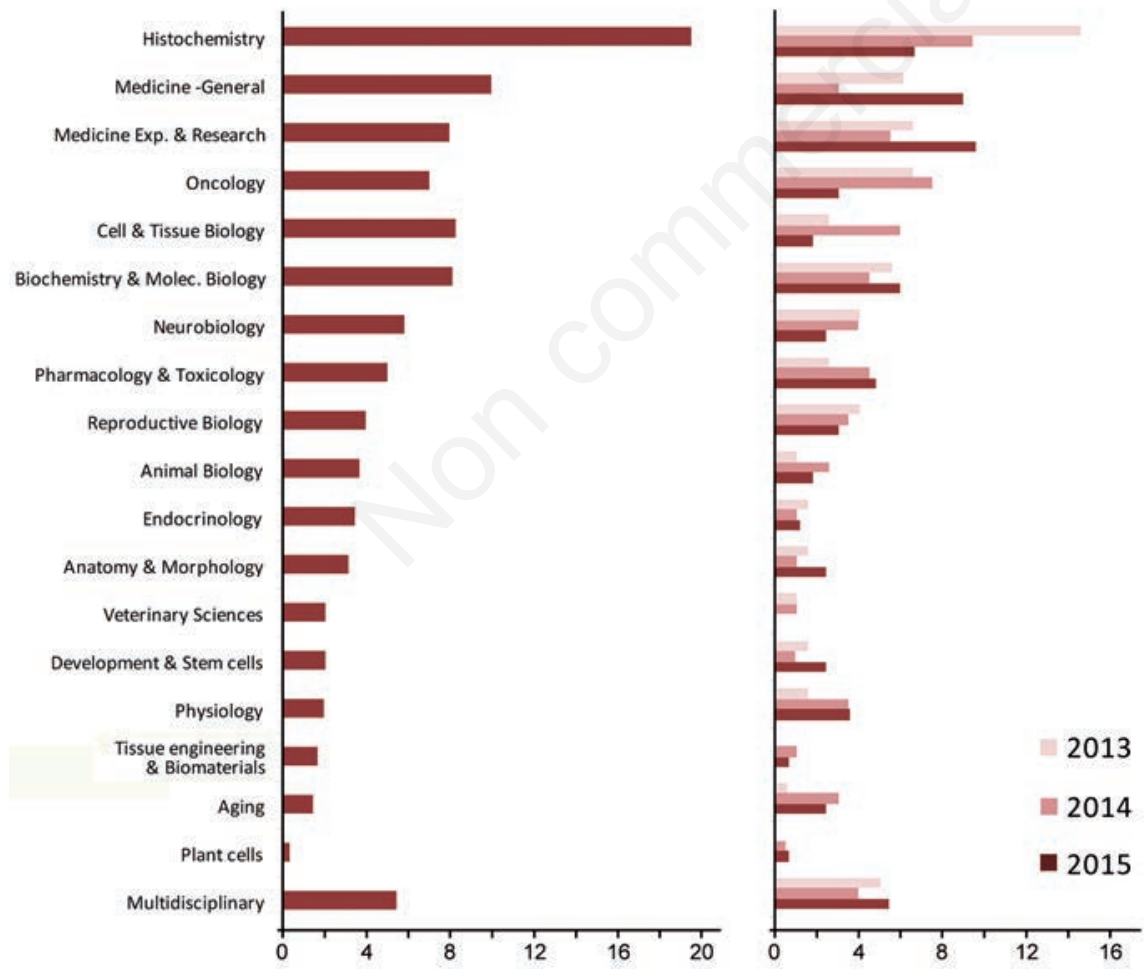

Figure 3. a) Percentage of citations in qualified journals of the articles published in the European Journal of Histochemistry in 2011-2015; the citing journals have been grouped according to their main topic and the first subject category in Thomson Reuters' Journal Citation Report. b) Percentage of citations obtained from the different journals' categories in the years 2013, 2014 and 2015 by the articles published in the European Journal of Histochemistry in 2011-2012. period 2011-2015 in this Journal have been cited in 340 different periodicals. Figure $3 \mathrm{a}$ shows the percentage of citations in these journal which have been grouped according to their main topic and their first subject category reported in the Thomson Reuters' Journal Citation Reports.

As expected, the journals on histochemistry were those in which the articles published in the European Journal of Histochemistry were most frequently cited. In agreement with the evidence in Figure 1 and 2, a large fraction of the citations were in medical journals (dealing with both general and experimental medicine, and with oncology), and in journals on cell and tissue biology or on biochemistry and molecular biology.

In most of the articles published in the European Journal of Histochemistry, specific molecular complexes were detected, and their structural location in cells and tissues was related with function. In addition, several papers also described new methods or presented improvements of well-established techniques thus providing new opportunities for application to a wide variety of research subjects. It is therefore not surprising that citations are frequently found in journals of Neurobiology, Anatomy \& Morphology, Pharmacology \& Toxicology, Reproductive biology, Veterinary sciences, Physiology, Endocrinology, Tissue engineering \& Biomaterials, Plant cell biology, as well as in multidisciplinary journals; significantly, the citations in histochemical journals of the articles published in 2011 and 2012 progressively decreased from 2013 to 2015 , while increasing during the same timespan in the journal of medicine, pharmacology, physiology and tissue engineering (Figure $3 \mathrm{~b}$ ).

\section{Concluding remarks}

In the last couple of decades, histochemistry has become a true molecular biology in situ, aimed at detecting single molecules in the very place where their functional role is exerted. The potential of histochemistry for diagnosis and prognosis has greatly increased by the use of refined techniques for investigating gene expression in situ. Vital histochemistry (chiefly, enzyme histochemistry ${ }^{127}$ ) provides evidence of the biochemical events driving and controlling cell physiology. The recent technological improvements in super-resolved light microscopy and in electron microscopy ${ }^{3,128,129}$ as well as the progress in correlative microscopy, ${ }^{130}$ and in imaging molecules in vivo $^{131,132}$ allowed to shed light on the molecular processes responsible for cell differentiation or which account for the onset a patholog- 
ical condition.

It is easy to foresee that, in the future, the histochemical journals will ever more be an attended forum for basic and applied scientists in the biomedical field.

But a journal of histochemistry should also be open to an audience as varied as possible within the biological area, publishing articles on organ, tissue and cell biology in very different experimental models. This open-minded attitude will keep histochemistry fresh and vital, and will also be beneficial for histochemical journals: offering hints for the applications of histochemical techniques also to non-histochemist scientists will expectedly increase the number of potential authors, thus expanding the research horizon to novel and possibly exclusive subjects.

\section{References}

1. Nelson AJ, Hess ST. Localization microscopy: mapping cellular dynamics with single molecules. J Microsc 2014;254:1-8.

2. Kusumi A, Tsunoyama TA, Hirosawa KM, Kasai RS, Fujiwara TK. Tracking single molecules at work in living cells. Nat Chem Biol 2014;10:524-32.

3. Montgomery PC1, Leong-Hoi A1. Emerging optical nanoscopy techniques. Nanotechnol Sci Appl. 2015;8:31-44.

4. Taatjes DJ, Roth J. The Histochemistry and Cell Biology pandect: the year 2014 in review. Histochem Cell Biol 2015;143:33968.

5. Donizy P, Halon A, Surowiak P, Pietrzyk G, Kozyra C, Matkowski R. Correlation between PARP-1 immunoreactivity and cytomorphological features of parthanatos a specific cellular death in breast cancer cells. Eur J Histochem 2013;57:e35.

6. Ferreira SA, Vasconcelos JLA, Silva RCWC, Cavalcanti CL, Bezerra CL, Rêgo MJ, et al. Expression patterns of alpha2 3sialyltransferase I and alpha2 6-sialyltransferase I in human cutaneous epithelial lesions. Eur J Histochem 2013;57:e7.

7. Huang S, Guo S, Guo F, Yang Q, Xiao X, Murata M, et al. CD44v6 expression in human skin keratinocytes as a possible mechanism for carcinogenesis associated with chronic arsenic exposure. Eur J Histochem 2013;57:e1.

8. Kadoglou NPE, Moustardas P, Kapelouzou A, Katsimpoulas M, Giagini A, Dede E, et al. The anti-inflammatory effects of exercise training promote atherosclerotic plaque stabilization in apolipoprotein $\mathrm{E}$ knockout mice with diabetic atherosclerosis. Eur J Histochem 2013;57:e3.
9. Latella G, Vetuschi A, Sferra R, Speca S, Gaudio E. Localization of alpha $v$ beta 6 integrin-TGF-beta $1 / \mathrm{Smad} 3 \mathrm{mTOR}$ and PPAR g in experimental colorectal fibrosis. Eur J Histochem 2013;57: e40.

10. Rappa F, Unti E, Baiamonte P, Cappello F, Scibetta N. Different immunohistochemical levels of Hsp60 and Hsp70 in a subset of brain tumors and putative role of Hsp60 in neuroepithelial tumorigenesis. Eur J Histochem 2013;57:e20 .

11. Salemi M, Galia A, Fraggetta F, La Corte C, Pepe P, La Vignera S, et al. Poly (ADPribose) polymerase 1 protein expression in normal and neoplastic prostatic tissue. Eur J Histochem 2013;57:e13.

12. Soddu S, Di Felice E, Cabras S, Castellanos ME, Atzori L, Faa G, et al. IMP3 expression in keratoacanthomas and squamous cell carcinomas of the skin: an immunohistochemical study. Eur J Histochem 2013;57:e6.

13. Xu XC, Abuduhadeer X, Zhang WB, Li T, Gao H, Wang YH. Knockdown of RAGE inhibits growth and invasion of gastric cancer cells. Eur J Histochem 2013;57: e36.

14. Zhang Y, Ye WY, Wang JQ, Wang SJ, Ji P, Zhou GY, et al. dCTP pyrophosphohydrase exhibits nucleic accumulation in multiple carcinomas. Eur J Histochem 2013;57:e29 .

15. Zhang Y, Tang YJ, Li ZH, Pan F, Huang K, $\mathrm{Xu}$ GH. KiSS1 inhibits growth and invasion of osteosarcoma cells through inhibition of the MAPK pathway. Eur $J$ Histochem 2013;57:e30-

16. Araujo DGB, Nakao L, Gozzo P, Souza CD, Balderrama V, Gugelmin ES, et al. Expression level of quiescin sulfhydryl oxidase 1 (QSOX1) in neuroblastomas. Eur J Histochem 2014;58:2228.

17. Arcucci A, Ruocco MR, Albano F, Granato G, Romano V, Corso G, et al. Analysis of extracellular superoxide dismutase and Akt in ascending aortic aneurysm with tricuspid or bicuspid aortic valve. Eur J Histochem 2014;58:2383.

18. Buldak RJ, Skonieczna M, Buldak L, Matysiak N, Mielanczyk $Ł$, Wyrobiec G, et al. Changes in subcellular localization of visfatin in human colorectal HCT-116 carcinoma cell line after cytochalasin B treatment. Eur J Histochem 2014;58:2408.

19. Chene G, Radosevic-Robin N, Tardieu AS, Cayre A, Raoelfils I, Dechelotte P, et al. Morphological and immunohistochemical study of ovarian and tubal dysplasia associated with tamoxifen. Eur J Histochem 2014;58:2251.

20. Clark ATR, Guimaraes da Costa VML, Bandeira Costa L, Bezerra Cavalcanti CL, De Melo Rêgo MJ, Beltrão EI. Differential expression patterns of $\mathrm{N}$-acetylglu- cosaminyl transferases and polylactosamines in uterine lesions. Eur $\mathrm{J}$ Histochem 2014;58:2334.

21. Demirovic A, Cesarec S, Marusic Z, Tomas D, Milošević M, Hudolin T, et al. TGF-betal expression in chromophobe renal cell carcinoma and renal oncocytoma. Eur J Histochem 2014;58:2265.

22. Demurtas P, Corrias M, Zucca I, Maxia C, Piras F, Sirigu P, et al. Angiotensin II: immunohistochemical study in Sardinian pterygium. Eur J Histochem 2014;58:2426.

23. Guerriero E, Accardo M, Capone F, Colonna G, Castello G, Costantini S. Assessment of the Selenoprotein M (SELM) over-expression on human hepatocellular carcinoma tissues by immunohistochemistry. Eur J Histochem 2014;58:2433.

24. Hu SS, Mei L, Chen JY, Huang ZW, Wu H. Expression of immediate-early genes in the inferior colliculus and auditory cortex in salicylate-induced tinnitus in rat. Eur $\mathrm{J}$ Histochem 2014;58:2294.

25. Karavana VN, Gakiopoulou H, Lianos EA. Expression of Ser729 phosphorylated PKCepsilon in experimental crescentic glomerulonephritis: an immunohistochemical study. Eur J Histochem 2014;58: 2308.

26. Lindstrom AK, Hellberg D. Immunohistochemical LRIG3 expression in cervical intraepithelial neoplasia and invasive squamous cell cervical cancer: association with expression of tumor markers hormones high-risk HPV-infection smoking and patient outcome. Eur J Histochem 2014;58:2227.

27. Tarantola E, Bertone V, Milanesi G, Gruppi C, Ferrigno A, Vairetti $M$, et al. Dipeptidylpeptidase-IV activity and expression reveal decreased damage to the intrahepatic biliary tree in fatty livers submitted to subnormothermic machine-perfusion respect to conventional cold storage. Eur J Histochem 2014;58:2414.

28. Theunissen W, Fanni D, Nemolato S, Di Felice E, Cabras T, Gerosa C, et al. Thymosin beta 4 and thymosin beta 10 expression in hepatocellular carcinoma. Eur J Histochem 2014;58:2242.

29. Zhang J, Luo J, Ni J, Tang L, Zhang HP, Zhang L, et al. MMP-7 is upregulated by COX-2 and promotes proliferation and invasion of lung adenocarcinoma cells. Eur J Histochem 2014;58:2262.

30. Janiuk I, Kasacka I. Quantitative evaluation of CART-containing cells in urinary bladder of rats with renovascular hypertension. Eur J Histochem 2015;59:2446.

31. Di Vito A, Scali E, Ferraro G, Mignogna C, Presta I, Camastra C, et al. Elastofibroma dorsi: a histochemical and immunohistochemical study. Eur J Histochem 2015;59: 
2459 .

32. Costanzo M, Cisterna B, Vella A, Cestari T, Covi V, Tabaracci G, et al. Low ozone concentrations stimulate cytoskeletal organization, mitochondrial activity and nuclear transcription. Eur J Histochem 2015;59: 2515.

33. Costa YF, Tjioe KC, Nonogaki S, Soares FA, Pereira Lauris JR, Oliveira DT. Are podoplanin and ezrin involved in the invasion process of the ameloblastomas? Eur J Histochem 2015;59:2451.

34. Fantinato E, Milani L, Sironi G. Sox9 expression in canine epithelial skin tumors. Eur J Histochem 2015;59:2514.

35. Di Nisio C, Zizzari VL, Zara S, Falconi M, Teti G, Tetè G, et al. RANK/RANKL/OPG signaling pathways in necrotic jaw bone from bisphosphonate-treated subjects. Eur J Histochem 2015;59:2455

36. Ferreira Junior M, Batista SA, Vidigal PVT, Cordeiro AAC, Oliveira FMS, Prata LO, et al. Infection with CagA-positive Helicobacter pylori strain containing three EPIYA C phosphorylation sites is associated with more severe gastric lesions in experimentally infected Mongolian gerbils (Meriones unguiculatus). Eur J Histochem 2015;59:2489.

37. Guerriero E, Capone F, Accardo M, Sorice A, Costantini M, Colonna G, et al. GPX4 and GPX7 over-expression in human hepatocellular carcinoma tissues. Eur J Histochem 2015;59:2540.

38. Iachettini S, Valaperta R, Marchesi A, Cuomo G, Fossati B Vaienti L, et al. Tibialis anterior muscle needle biopsy and sensitive biomolecular methods: a useful tool in myotonic dystrophy type 1 . Eur J Histochem 2015;59:2562.

39. Goteri G, Altobelli E, Tossetta G, Zizzi A, Avellini C, Licini C, et al. High temperature requirement $\mathrm{Al}$, transforming growth factor beta1, phosphoSmad2 and Ki67 in eutopic and ectopic endometrium of women with endometriosis. Eur J Histochem 2015;59:2570.

40. Leonardi R, Perrotta RE, Loreto C, Musumeci G, Crimi S, dos Santos JN, et al. Toll-like receptor 4 expression in the epithelium of inflammatory periapical lesions. An immunohistochemical study. Eur J Histochem 2015;59:2547.

41. San Martin S, Fitzgerald JS, Weber M, Parraga M, Sáez T, Zorn TM, et al. STAT3 and SOCS3 expression patterns during murine placenta development. Eur J Histochem 2013;57:e19.

42. $\mathrm{Xu} \mathrm{X}$, Guan $\mathrm{S}$, He B, Wang J. Active role of the predecidual-like zone in endometrial shedding in a mouse menstrual-like model. Eur J Histochem 2013;57:e25.

43. Sandhu MA, Saeed AA, Khilji MS, Pasha
RH, Mukhtar N, Anjum MS. Ontogenic development of corticotrophs in fetal buffalo (Bubalus bubalis) pituitary gland. Eur J Histochem 2014;58:2292.

44. Song JH, Lee MY, Kim YJ, Park SR, Kim J, Ryu SY, et al. Developmental immunolocalization of the Klotho protein in mouse kidney epithelial cells. Eur J Histochem 2014;58:2256.

45. Ambu R, Vinci L, Gerosa C, Fanni D, Obinu E, Faa A, V. Fanos WT1 expression in the human fetus during development. Eur J Histochem 2015;59:2499.

46. Ferretti V, Segal-Eiras A, Barbeito CG, Croce MV. Muc5ac mucin expression during rat skin development. Eur J Histochem 2015;59:2462.

47. Di Felice V, Zummo G. Stem cell populations in the heart and the role of Isll positive cells. Eur J Histochem 2013;57:e14.

48. Miko M, Danisovic L, Majidi A, Varga I. Ultrastructural analysis of different human mesenchymal stem cells after in vitro expansion: a technical review. Eur J Histochem 2015;59:2528.

49. Fujikawa K, Yokohama-Tamaki T, Morita T, Baba 0, Qin C, Shibata S. An in situ hybridization study of perlecan, DMP1, and MEPE in developing condylar cartilage of the fetal mouse mandible and limb bud cartilage. Eur J Histochem 2015;59:2553.

50. Carvalho de Moraes L0, Tedesco RC, Arraez-Aybar LA, Klein 0, Mérida-Velasco JR, Alonso LG. Development of synovial membrane in the temporomandibular joint of the human fetus. Eur J Histochem 2015;59:2569.

51. Orsini G, Majorana A, Mazzoni A Putignano A, Falconi M, Polimeni A, et al. Immunocytochemical detection of dentin matrix proteins in primary teeth from patients with dentinogenesis imperfecta associated with osteogenesis imperfecta. Eur J Histochem 2014;58:2405.

52. Di Rosa M, Szychlinska M A, Tibullo D, Malaguarnera L, Musumeci G. Expression of CHI3L1 and CHIT1 in osteoarthritic rat cartilage model. A morphological study. Eur J Histochem 2014;58:2423

53. Musumeci G, Castrogiovanni P, Mazzone V, Szychlinska MA, Castorina S, Loreto C. Histochemistry as a unique approach for investigating normal and osteoarthritic cartilage. Eur J Histochem 2014;58:2371.

54. Loreto C, Galanti C, Musumeci G, Rusu MC, Leonardi R. Immunohistochemical analysis of matrix metalloproteinase- 13 in human caries dentin. Eur J Histochem 2014;58:2318.

55. Martini D, Trirè A, Breschi L, Mazzoni A, Teti G, Falconi M, et al. Dentin matrix protein 1 and dentin sialophosphoprotein in human sound and carious teeth: an immunohistochemical and colorimetric assay. Eur J Histochem 2013;57:e32.

56. Loreto C, Psaila A, Musumeci G, Castorina S, Leonardi R. Apoptosis activation in human carious dentin. An immunohistochemical study. Eur J Histochem 2015;59: 2513.

57. Loreto C, Leonardi R, Musumeci G, Pannone G, Castorina S. An ex vivo study on immunohistochemical localization of MMP-7 and MMP-9 in temporomandibular joint discs with internal derangement. Eur J Histochem 2013;57:e12.

58. Shinohara Y, Okamoto K, Goh Y, Kiga N, Tojyo I, Fujita S. Inhibition of fibrous adhesion formation in the temporomandibular joint of tenascin-C knockout mice. Eur J Histochem 2014;58:2337.

59. Okamoto K, Kiga N, Shinohara Y, Tojyo I, Fujita S. Effect of interleukin-1beta and dehydroepiandrosterone on the expression of lumican and fibromodulin in fibroblast-like synovial cells of the human temporomandibular joint. Eur J Histochem 2015;59:2440.

60. Tsukamoto I, Akagi M, Inoue S, Yamagishi K, Mori S, Asada S. Expressions of local renin-angiotensin system components in chondrocytes. Eur J Histochem 2014;58: 2387.

61. Xu H, Zhang X, Wang H, Shi Y, Zhang X. Continuous cyclic mechanical tension increases ank expression in endplate chondrocytes through the TGF-betal and p38 pathway. Eur J Histochem 2013; $57: \mathrm{e} 28$.

62. Xu HG, Zhang W, Zheng Q, Yu YF, Deng LF, Wang $\mathrm{H}$, et al. Investigating conversion of endplate chondrocytes induced by intermittent cyclic mechanical unconfined compression in three-dimensional cultures. Eur J Histochem 2014;58:2415.

63. Teti G, Salvatore V, Ruggeri A, Manzoli L, Gesi M, Orsini G, et al. In vitro reparative dentin: a biochemical and morphological study. Eur J Histochem 2013;57:e23.

64. Dall'Oca C, Maluta T, Cavani F, Morbioli P, Bernardi P, Sbarbati A, et al. The biocompatibility of porous vs non-porous bone cements: a new methodological approach. Eur J Histochem 2014;58:2255.

65. Lehmann M, Martin F, Mannigel K, Kaltschmidt K, Sack U, Anderer U. Threedimensional scaffold-free fusion culture: the way to enhanced chondrogenesis of in vitro propagated human articular chondrocytes. Eur J Histochem 2013;57:e31.

66. Porzionato A, Sfriso MM, Macchi V, Rambaldo A, Lago G, Lancerotto L, et al. Decellularized omentum as novel biologic scaffold for reconstructive surgery and regenerative medicine. Eur $\mathrm{J}$ Histochem 2013;57:e4. 
67. Tetè $S$, Vinci R, Zizzari V L, Zara $S$, La Scala V, Cataldi A, et al. Maxillary sinus augmentation procedures through equinederived biomaterial or calvaria autologous bone: immunohistochemical evaluation of OPG/RANKL in humans. Eur J Histochem 2013;57:e10 .

68. De Nevi E, Marco-Salazar P, Fondevila D, Blasco E, Perez L, Pumarola M. Immunohistochemical study of doublecortin and nucleostemin in canine brain. Eur J Histochem 2013;57:e9.

69. Natale G, Pompili E, Biagioni F, Paparelli S, Lenzi P, Fornai F. Histochemical approaches to assess cell-to-cell transmission of misfolded proteins in neurodegenerative diseases. Eur J Histochem 2013; 57:e5.

70. Pelz J, Haertig W, Weise C, Hobohm C, Schneider D, Krueger M, et al. Endothelial barrier antigen-immunoreactivity is conversely associated with blood-brain barrier dysfunction after embolic stroke in rats. Eur J Histochem 2013;57:e38.

71. Ragionieri L, Botti M, Gazza F, Sorteni C, Chiocchetti R, Clavenzani $\mathrm{P}$, et al. Localization of peripheral autonomic neurons innervating the boar urinary bladder trigone and neurochemical features of the sympathetic component. Eur J Histochem 2013;57:e16.

72. Insolia V, Piccolini VM. Brain morphological defects in prolidase deficient mice: first report. Eur J Histochem 2014;58:2417.

73. Romero-Fernandez W, Borroto-Escuela D0, Vargas-Barroso V, Narváez M, Di Palma M, Agnati LF, et al. Dopamine D1 and $\mathrm{D} 2$ receptor immunoreactivities in the arcuate-median eminence complex and their link to the tubero-infundibular dopamine neurons. Eur J Histochem 2014;58:2400.

74. Salucci S, Ambrogini P, Lattanzi D, Betti M, Gobbi P, Galati C, et al. Maternal dietary loads of alpha-tocopherol increase synapse density and glial synaptic coverage in the hippocampus of adult offspring. Eur $\mathbf{J}$ Histochem 2014;58:2355.

75. Sun Y, Zhu L, Huang X, Zhou C, Zhang X. Immunohistochemical localization of nerve fibers in the pseudocapsule of fibroids. Eur J Histochem 2014;58:2249.

76. Curzi D., Lattanzi D., Ciuffoli S., Burattini S, Grindeland RE, Edgerton VR, et al. Growth hormone plus resistance exercise attenuate structural changes in rat myotendinous junctions resulting from chronic unloading Eur $\mathrm{J}$ Histochem 2013;57: e37

77. Kocsis T, Baan J, Muller G, Mendler L, Dux L, Keller-Pintér A. Skeletal muscle cellularity and glycogen distribution in the hypermuscular Compact mice. Eur J Histochem
2014;58:2353.

78. Malatesta M, Giagnacovo M, Costanzo M, Cisterna B, Cardani R, Meola G. Muscleblind-likel undergoes ectopic relocation in the nuclei of skeletal muscles in myotonic dystrophy and sarcopenia. Eur J Histochem 2013;57:e15.

79. Renna LV, Cardani R, Botta A, Rossi G, Fossati B, Costa E et al. Premature senescence in primary muscle cultures of myotonic dystrophy type 2 is not associated with p16 induction. Eur J Histochem 2014;58:2444.

80. Severi C, Sferra R, Scirocco A, Vetuschi A, Pallotta N, Pronio A, et al. Contribution of intestinal smooth muscle to Crohn's disease fibrogenesis. Eur J Histochem 2014; 58:2457.

81. Varricchio E, Russolillo MG, Maruccio L, Velotto S, Campanile G, Paolucci M, et al. Immunological detection of $\mathrm{m}$ - and $\mu$-calpains in the skeletal muscle of Marchigiana cattle. Eur J Histochem 2013; $57: \mathrm{e} 2$.

82. Gomes FM, Ramos IB, Wendt C, GirardDias W, De Souza W, Machado EA, et al. New insights into the in situ microscopic visualization and quantification of inorganic polyphosphate stores by 4 ' 6 diamidino-2-phenylindole (DAPI)-staining. Eur J Histochem 2013;57:e34.

83. Malatesta M, Zancanaro C, Costanzo M, Cisterna B, Pellicciari C. Simultaneous ultrastructural analysis of fluorochromephotoconverted diaminobenzidine and gold immunolabelling in cultured cells. Eur J Histochem 2013;57:e26.

84. Osman TA, Oijordsbakken G, Costea DE, Johannessen AC. Successful triple immunoenzymatic method employing primary antibodies from same species and same immunoglobulin subclass. Eur J Histochem 2013;57:e22.

85. Rieger J, Twardziok S, Huenigen $\mathrm{H}$, Hirschberg RM, Plendl J. Porcine intestinal mast cells. Evaluation of different fixatives for histochemical staining techniques considering tissue shrinkage. Eur J Histochem 2013;57:e21.

86. Rizzatti V, Boschi F, Pedrotti M, Zoico E, Sbarbati A, Zamboni M. Lipid droplets characterization in adipocyte differentiated 3T3-L1 cells: size and optical density distribution. Eur J Histochem 2013;57:e24.

87. Ami D, Di Segni M, Forcella M, Meraviglia V, Baccarin M, Doglia SM, et al. Role of water in chromosome spreading and swelling induced by acetic acid treatment: a FTIR spectroscopy study. Eur J Histochem 2014;58:2330.

88. Cabibi D, Giannone AG, Mascarella C, Guarnotta C, Castiglia M, Pantuso G, et al. Immunohistochemical/histochemical dou- ble staining method in the study of the columnar metaplasia of the oesophagus. Eur J Histochem 2014;58:2326.

89. Croce AC, Bottiroli G. Autofluorescence spectroscopy and imaging: a tool for biomedical research and diagnosis. Eur $\mathrm{J}$ Histochem 2014;58:2461.

90. Derenzini M, Olins AL, Olins DE. Chromatin structure in situ: the contribution of DNA ultrastructural cytochemistry. Eur J Histochem 2014;58:2307.

91. Emde B, Heinen A, Godecke A, Bottermann $\mathrm{K}$. Wheat germ agglutinin staining as a suitable method for detection and quantification of fibrosis in cardiac tissue after myocardial infarction. Eur $\mathrm{J}$ Histochem 2014;58:2448.

92. Fede C, Fortunati I, Petrelli L, Guidolin D, De Caro R, Ferrante C, et al. An easy-tohandle microfluidic device suitable for immunohistochemical procedures in mammalian cells grown under flow conditions. Eur J Histochem 2014;58:2360.

93. Grecchi S, Malatesta M. Visualizing endocytotic pathways at transmission electron microscopy via diaminobenzidine photooxidation by a fluorescent cell-membrane dye. Eur J Histochem 2014;58:2449 .

94. Kammoun M, Cassar-Malek , Meunier B, Picard B. A simplified immunohistochemical classification of skeletal muscle fibres in mouse. Eur J Histochem 2014;58:2254.

95. Perdoni F, Falleni M, Tosi D, Cirasola D, Romagnoli S, Braidotti P, et al. A histological procedure to study fungal infection in the wax moth Galleria mellonella. Eur J Histochem 2014;58:2428.

96. Scimeca M, Orlandi A, Terrenato I, Bischetti S, Bonanno E. Assessment of metal contaminants in non-small cell lung cancer by EDX microanalysis. Eur J Histochem 2014;58:2403.

97. Rieger J, Janczyk P, Huenigen H, Plendl J. Enhancement of immunohistochemical detection of Salmonella in tissues of experimentally infected pigs. Eur J Histochem 2015;59:2516.

98. Bonetti A, Bonifacio A, Della Mora A, Livi U, Marchini M, Ortolani F. Carotenoids colocalize with hydroxyapatite, cholesterol, and other lipids in calcified stenotic aortic valves. Ex vivo Raman maps compared to histological patterns. Eur J Histochem 2015;59:2505.

99. KorzhevskiiDE, Sukhorukova EG, Kirik OV, Grigorev IP. Immunohistochemical demonstration of specific antigens in the human brain fixed in zinc-ethanol-formaldehyde. Eur J Histochem 2015;59:2530.

100.Di Guardo G. Lipofuscin, lipofuscin-like pigments and autofluorescence. Eur J Histochem 2015;59:2485.

101.Sainz Jr B, Miranda-Lorenzo I, Heeschen 
C. The fuss over lipo"fuss"cin: not all autofluorescence is the same. Eur J Histochem 2015;59:2512.

102.Croce AC, Bottiroli G. New light in flavin autofluorescence. Eur j Histochem 2015;59:2576.

103.Lee A, Anderson AR, Stevens M, Beasley S, Barnett NL, Pow DV. Excitatory amino acid transporter 5 is widely expressed in peripheral tissues. Eur J Histochem 2013;57:e11.

104.May CA, Osterland I. Merkel cell distribution in the human eyelid. Eur J Histochem 2013;57:e33.

105.Meyer W, Liumsiricharoen M, Suprasert A, Fleischer LG, Hewicker-Trautwein M. Immunohistochemical demonstration of keratins in the epidermal layers of the Malayan pangolin (Manis javanica) with remarks on the evolution of the integumental scale armour. Eur J Histochem 2013;57:e27.

106.Meyer W, Kacza J, Hornickel IN, Schoennagel B. Immunolocalization of succinate dehydrogenase in the esophagus epithelium of domesticated mammals. Eur J Histochem 2013;57:e18.

107.Negrato E, Vascellari M, Capolongo F, Binato G, Da Dalt L, Boscolo Papo M, et al. Expression of 8-0HdG in Zosterisessor ophiocephalus from the Venetian lagoon Italy. Eur J Histochem 2013;57:e8.

108.Nemolato S, Ekstrom J, Cabras T, Gerosa C, Fanni D, Di Felice E, et al. Immunoreactivity for thymosin beta 4 and thymosin beta 10 in the adult rat oro-gastrointestinal tract. Eur J Histochem 2013;57:e17.

109.Akat E, Arikan H, Gocmen B. Histochemical and biometric study of the gastrointestinal system of Hyla orientalis (Bedriaga 1890) (Anura Hylidae). Eur J Histochem 2014;58:2452.

110.Bao L, Li Q, Liu Y, Sheng X, Han Y, Weng Q. Immunolocalization of NGF and its receptors in ovarian surface epithelium of the wild ground squirrel during the breeding and nonbreeding seasons. Eur J Histochem 2014;58:2363.

111.Caprara GA, Perni S, Morabito C, Mariggiò MA, Guarnieri S. Specific association of growth-associated protein 43 with calcium release units in skeletal muscles of lower vertebrates. Eur J Histochem 2014;58: 2453.

112.Golic I, Velickovic K, Markelic M, Stancic A, Jankovic A, Vucetic M, et al. Calciuminduced alteration of mitochondrial morphology and mitochondrial-endoplasmic reticulum contacts in rat brown adipocytes. Eur J Histochem 2014;58 $: 2377$.

113.Liu Y, Weng J, Huang S, Shen Y, Sheng X, Han Y, et al. Immunoreactivities of PPARgamma2 leptin and leptin receptor in oviduct of Chinese brown frog during breeding period and pre-hibernation. Eur J Histochem 2014;58:2422.

114.0u JM, Yu ZY, Qiu MK, Dai YX, Dong Q, Shen J, et al. Knockdown of VEGFR2 inhibits proliferation and induces apoptosis in hemangioma-derived endothelial cells. Eur J Histochem 2014;58:2263.

115.Suchankova J, Legartova S, Sehnalova P, Kozubek S, Valente S, Labella D, et al. PRMT1 arginine methyltransferase accumulates in cytoplasmic bodies that respond to selective inhibition and DNA damage. Eur J Histochem 2014;58:2389.

116.Strobel S, Encarnação JA, Becker NI, Trenczek TE. Histological and histochemical analysis of the gastrointestinal tract of the common pipistrelle bat (Pipistrellus pipistrellus). Eur J Histochem 2015;59: 2477.

117.Zhang H, Guo X, Zhong S, Ge T, Peng S, Yu $\mathrm{P}$, et al. Heterogeneous vesicles in mucous epithelial cells of posterior esophagus of Chinese giant salamander (Andrias davidianus). Eur J Histochem 2015;59:2521.

118.Cutroneo G, Centofanti A, Speciale F, Rizzo G, Favaloro A, Santoro G, et al. Trimarchi Sarcoglycan complex in masseter and sternocleidomastoid muscles of baboons: an immunohistochemical study. Eur J Histochem 2015;59:2509.

119.Zhang H, Wang Y, Zhang J, Wang L, Li Q, X Sheng, et al. Testicular expression of NGF, TrkA and p75 during seasonal spermatogenesis of the wild ground squirrel (Citellus dauricus Brandt). Eur J Histochem 2015; 59:2522.

120.Escobar ML, Echeverría M, Garcia G, Ortiz R, Vázquez-Nin GH. Immunohistochemical and ultrastructural study of the lamellae of oocytes in atretic follicles in relation to dif- ferent processes of cell death. Eur J Histochem 2015;59:2535.

121.Zhang Y, Wang J, Cheng X, Yi B, Zhang X, Li Q. Apigenin induces dermal collagen synthesis via smad2/3 signaling pathway. Eur J Histochem 2015;59:2467.

122.Seliverstova EV, Prutskova NP. Receptormediated endocytosis of lysozyme in renal proximal tubules of the frog Rana temporaria. Eur J Histochem 2015;59:2482.

123.Porzionato A, Rucinski M, Macchi V, Sarasin G, Malendowicz LK, De Caro R. ECRG4 expression in normal rat tissues: expression study and literature review. Eur J Histochem 2015;59:2458.

124.Cobo T, Obaya A, Cal S, Solares L, Cabo R, Vega JA, et al. Immunohistochemical localization of periostin in human gingiva. Eur J Histochem 2015;59:2548.

125.Li Q, Zhang F, Zhang S, Sheng X, Han X, Weng $Q$, et al. Seasonal expression of androgen receptor, aromatase, and estrogen receptor alpha and beta in the testis of the wild ground squirrel (Citelluhs dauricus Brandt). Eur J Histochem 2015;59: 2456.

126.Aredia F, Malatesta M, Veneroni P, Bottone MG. Analysis of ERK3 intracellular localization: dynamic distribution during mitosis and apoptosis. Eur J Histochem 2015;59:2571.

127.Van Noorden CJF. Imaging enzymes at work: metabolic mapping by enzyme histochemistry. J Histochem Cytochem 2010;58: 481-97.

128.Sydor AM, Czymmek KJ, Puchner EM, Mennella V. Super-resolution microscopy: from single molecules to supramolecular assemblies. Trends Cell Biol 2015;25:73048.

129.Carroni M, Saibil HR. Cryo electron microscopy to determine the structure of macromolecular complexes. Methods 2015;pii: S1046-2023(15)30163-8.

130.Loussert Fonta C, Humbel BM. Correlative microscopy. Arch Biochem Biophys 2015;581:98-110.

131.Liu Z, Lavis LD, Betzig E. Imaging live-cell dynamics and structure at the single-molecule level. Mol Cell 2015;58:644-59.

132.Cox S. Super-resolution imaging in live cells. Dev Biol 2015;401:175-81. 